\title{
Dr Mieczyslaw Jan de Sas Kropiwnicki (1912-1971): The first Polish veterinarian to perform a caesarean section on a brood mare
}

\author{
MICHAEL KNOTT*,**, MACIEJ WITKOWSKI*** \\ *School of Pharmacy, University of Namibia, Windhoek, Namibia \\ **Gdański Uniwersytet Medyczny, ul. Marii Skłodowskiej-Curie 3a, 80-210 Gdańsk \\ ***Uniwersyteckie Centrum Medycyny Weterynaryjnej UJ-UR, al. Adama Mickiewicza 24/28, 30-059 Kraków
}

Knott M., Witkowski M.

Dr Mieczyslaw Jan de Sas Kropiwnicki (1912-1971):

The first Polish veterinarian to perform a caesarean section on a brood mare

Summary

The paper presents the life story of Dr Mieczysław Jan de Sas Kropiwnicki, Polish solder, member of the "Cichociemni" paratrooper group during World War II and a veterinarian, who practiced in RSA and who became famous after he had successfully performed a pioneering operation of a cesarean section on a mare in 1957. The tangled history of his life shows this great patriot entangled in the turbulent fates of the World War II and as a representative of our veterinarian profession, determined enough, to study veterinary medicine in Scotland (Edinburgh) once again, after his diploma from the Veterinary Medicine Academy in Lwów was lost, and then to nostrificate it to join the Royal College of Veterinary Surgeons to finally start his practice in RSA. A lot of details of Dr Kropiwnicki's life were elaborated on by one of the authors - his grandson, who was born and raised in Africa and finally settled in Poland - the country of his grandfather's origin, which was the place he had not been able to return to, but had been longing for all his life.

Keywords: pioneer c-section, mare, history

This story started many years ago, but more recently, after my grandmother's [Aleksandra (Olenkka) de Sas Kropiwnicka (née Hall)] death in January 2019, I discovered a Cichochiemni paratrooper wings badge at the bottom of her old jewellery box in East London, South Africa, as well as several of my grandfather's (Dr Mieczyslaw Jan de Sas Kropiwnicki) veterinary publications. From my side, as a scientist, this prompted even more interest in my grandfather's academic and military career. Who was this man who I had never met before? I was also told by my Grandmother that he was one of the first people to perform a caesarean section on a brood mare, but I was not sure how true this was either. I did some research on Google and found an excellent Polish review of a publication about caesarean sections on brood mares (1). I emailed all my questions to one of the main authors, Maciej Witkowski, and then we decided to write this paper about my Grandfather together. Much of the historical outline below is based on the book Oleńka in London by Aleksandra de Sas Kropiwnicka (née Hall) first published in 2018 (2).

Michael Knott

Mieczysław (Mietek) Jan de Sas Kropiwnicki was born in Niżniów, Poland, on the $24^{\text {th }}$ of February, 1912, in an old "szlachta" (gentry) family. He passed away on the $15^{\text {th }}$ of August, 1971, in East London, South Africa. During his life he was a brilliant veterinary surgeon, as well as a member of the Polish paratrooper group "Cichociemni".

Niżniów was a small town in a distant corner in the eastern part of Poland. It is situated close to the Dniester River. At the time of Mietek's early childhood, Niżniów belonged to the Austro-Hungarian province of Galicia. Mieczysław started school at King Kazimierz 
Jagiellończyk Gimnazjum in Kołomyja. The standard was very high and they had some of the best teachers in the province; men like Franciszek Kuś, who was a teacher of Polish literature, Kazimierz Misson, a German teacher, and Kazimierz Strutyński, who taught him mathematics and physics.

He started his army training (as a rifleman) on the $12^{\text {th }}$ of August, 1932, at the Infantry Military College situated in Grodno and was selected to be an Officer Cadet. Mieczysław was transferred into the Army reserve on the $2^{\text {nd }}$ September 1933.

He studied veterinary science at the Academy of Veterinary Science in Lwów (which was established in 1896) and was fascinated by anatomy and later surgery.

In the following year of his studies he was called to the Army service for five weeks in Stanisławów. He worked mainly as an interpreter while the Polish Army raided various villages in order to liquidate Ukrainian partisans. Mieczysław had to interview many men who were suspected of helping the Ukrainian partisans. He was promoted to Corporal in 1934 and in 1936 to Second Lieutenant (Fig. 1). Mieczysław was regarded as "Piłsudski's man" and he was often criticised for his blind obedience to Piłsudski.

Mieczysław's first marriage took place on the $23^{\text {rd }}$ of August 1937, in the parish church of St. Maria Magdalena, to Ela Doroszyńska.

In the spring of 1939, Mieczysław wrote his final veterinary science examinations and was offered a wellpaid job. He was to eradicate foot and mouth disease from the eastern part of the Carpathian Mountains. This experience with his wife, Ela, ended when one day a telegram arrived which had been re-addressed from Lwów to Niżniów and from there to the Forestry Department. Mieczysław was informed that he had to immediately report to the Army. They left at once and travelled to Niżniów. Then Mieczysław took the train to Stanisławów and on the $1^{\text {st }}$ of September, 1939, he reported to Captain Dutkiewicz of the $49^{\text {th }}$ Infantry Regiment for active service. On the same day the German navy attacked the Polish military post at Westerplatte and the German Army entered Poland at several border points. The Second World War had begun.

Mieczysław was assigned to the Regiment of Second Colonel Józef Szelęga and his duties were based in the garrison at Stanisławów. On the $5^{\text {th }}$ of September they received an order to march to Stryj. Mieczysław was in charge of the Second Platoon. From Stryj they marched to Strzałków to organise a defence. On the $15^{\text {th }}$ of September they marched back to Stryj and waited for further orders. On the $17^{\text {th }}$ of September they received news that the Soviets had crossed the eastern borders of Poland. In the mean time, he was sent with the First Platoon to cover the defence line between Grabowice and Lubience. It was there that they came under artillery fire. They suffered no casualties, but their

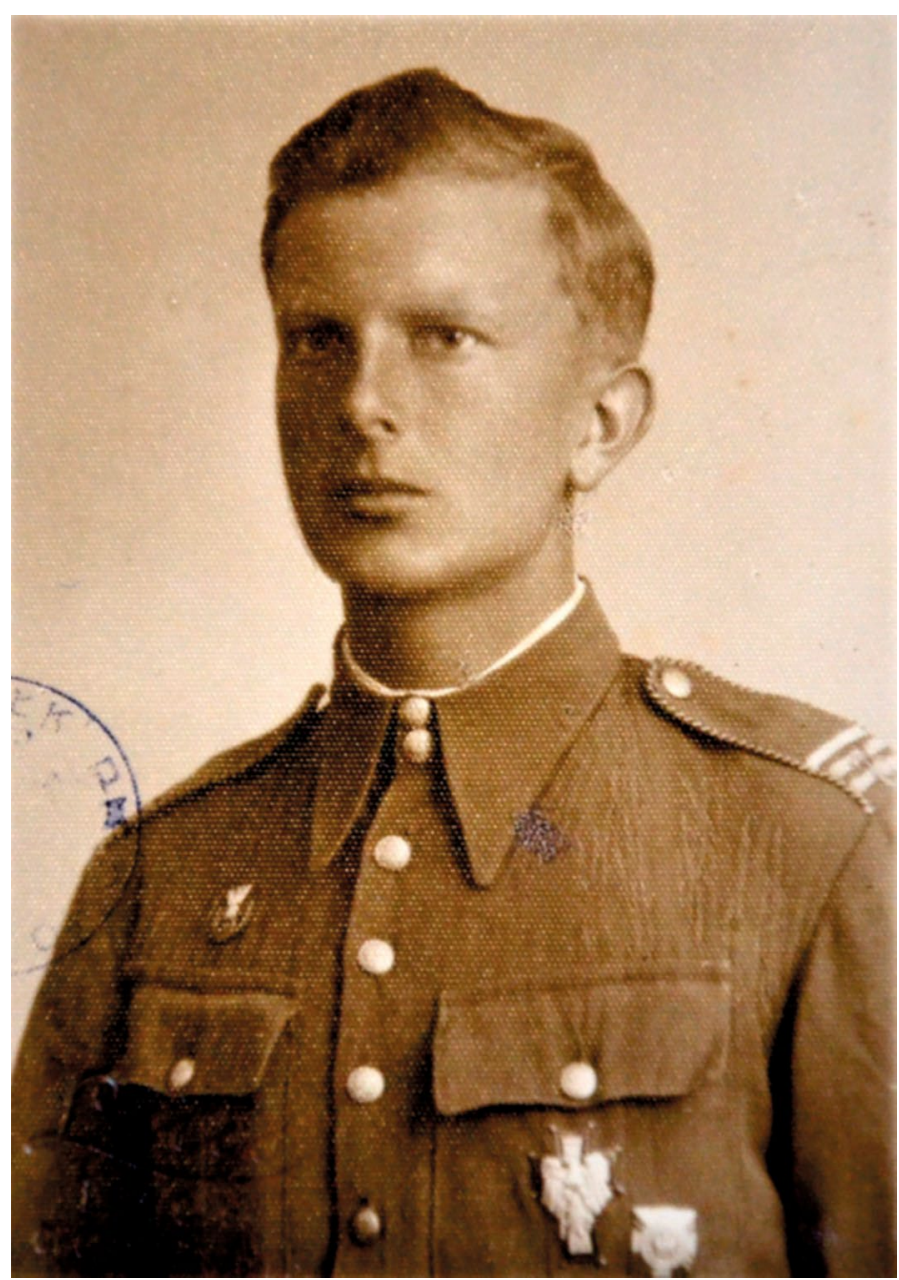

Fig. 1. Dr Mieczyslaw Jan Sas de Kropiwnicki before II World War

supply wagons were destroyed. They were told to cross the Hungarian border. General Rydz-Śmigły and his staff had already left Poland and were now in Romania. On the $21^{\text {st }}$ of September, they crossed the Hungarian border and the next day they surrendered their weapons. He was taken into custody and sent to a camp at Levél. In October of the same year Mieczysław tried to escape, but he was betrayed and captured and sent to a camp at Gyor. On the $3^{\text {rd }}$ February 1940 , he finally managed to escape to Budapest and from there he travelled to the border of Yugoslavia. At Barcz, he crossed the Drava River and finally reached Zagreb on the $9^{\text {th }}$ of February. Mieczysław eventually managed to get to Modena in Italy and from there he travelled to France. He did so in a nick of time, as it was just before Italy entered the war on the side of Germany. Mieczysław landed up at Camp de Carpiagne in Marseille. After verification he was sent to Val-André in Brittany. In June 1940, he was sent on a course to Granville, then to St. Malo and finally to Le Verdon. On the $22^{\text {nd }}$ of June as the defeat of France was evident, he embarked for England and reached Liverpool three days later. From there he travelled to Douglas in Scotland. He was assigned to the Canadian Rifle Brigade. From Douglas, he was transferred to the 
Second Canadian Rifle Brigade in Gratham, close to RAF Spitgate where Col. Stanisław Sosabowski was stationed. Their Brigade had changed its name to BKS, Brigade of Cadre Riflemen. In January 1941, he was sent on a rifle course at Fort William and then for a communication course in Dundee. In February 1941 Mieczysław attended a parachute course in Ringway and in June 1941, he completed a course in mechanics. In September 1941 their brigade had changed its name again, and the First Polish Independent Parachute Brigade of the Polish Armed Forces was created. Their Commander was Stanisław Sosabowski. On $23^{\text {rd }}$ September 1941, Mieczysław received his parachute token no. 0030. He was now a member of the Cichociemni (Fig. 2).

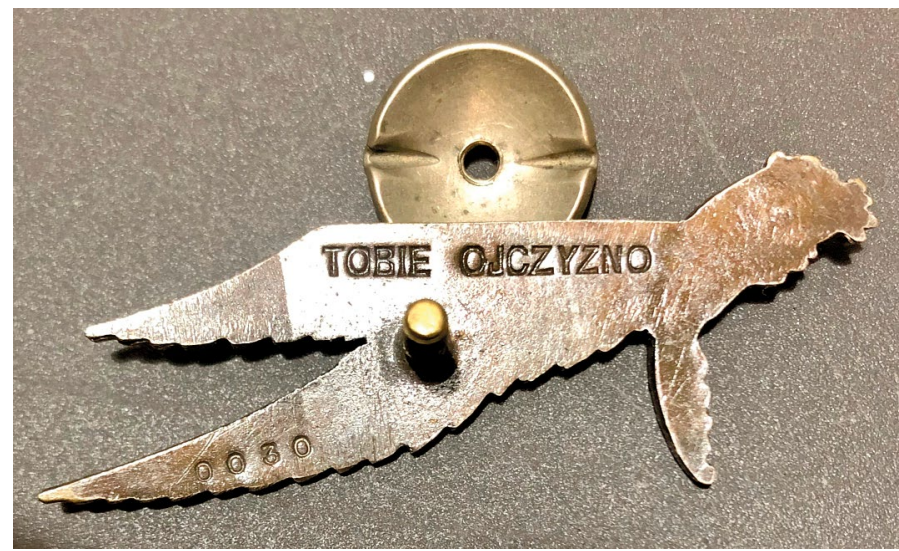

Fig. 2. Cichociemni paratrooper badge No 0030

Their brigade was directly responsible to the Polish Government in London and its goal was to parachute agents into occupied Poland and aid underground organisations. This was not acceptable to the British Government who wanted them to take part in action based in western Europe. The parachute agents sent to Poland were selected by the Polish Government in London and they were motivated mainly by their political association. Mieczysław felt disappointed and frustrated and wished to return to Poland as soon as possible. He was also motivated by a personal reason. He had received news that his wife had given birth to their son, Zdzisław Andrzej, on the $17^{\text {th }}$ of May, 1940. They were safe and were living in Kraków.

Mieczysław had passed the special guerrilla combatant course in London, named course ' $\mathrm{O}$ ' and was ready to be dropped into Poland. He was sure that that he would find a way during his work as a parachute agent or Cichochiemni to visit his family.

In the meantime, he was recalled to the staff of the High Command in London. There he met an Army Chaplain named Father Bełch with whom he made a close acquaintance. Father Bełch encouraged Mieczysław to think seriously of finishing his studies. Mieczysław was a graduate from Lwów Veterinary Academy, but he had no proof to show it. All his documents, together with his study record were left in

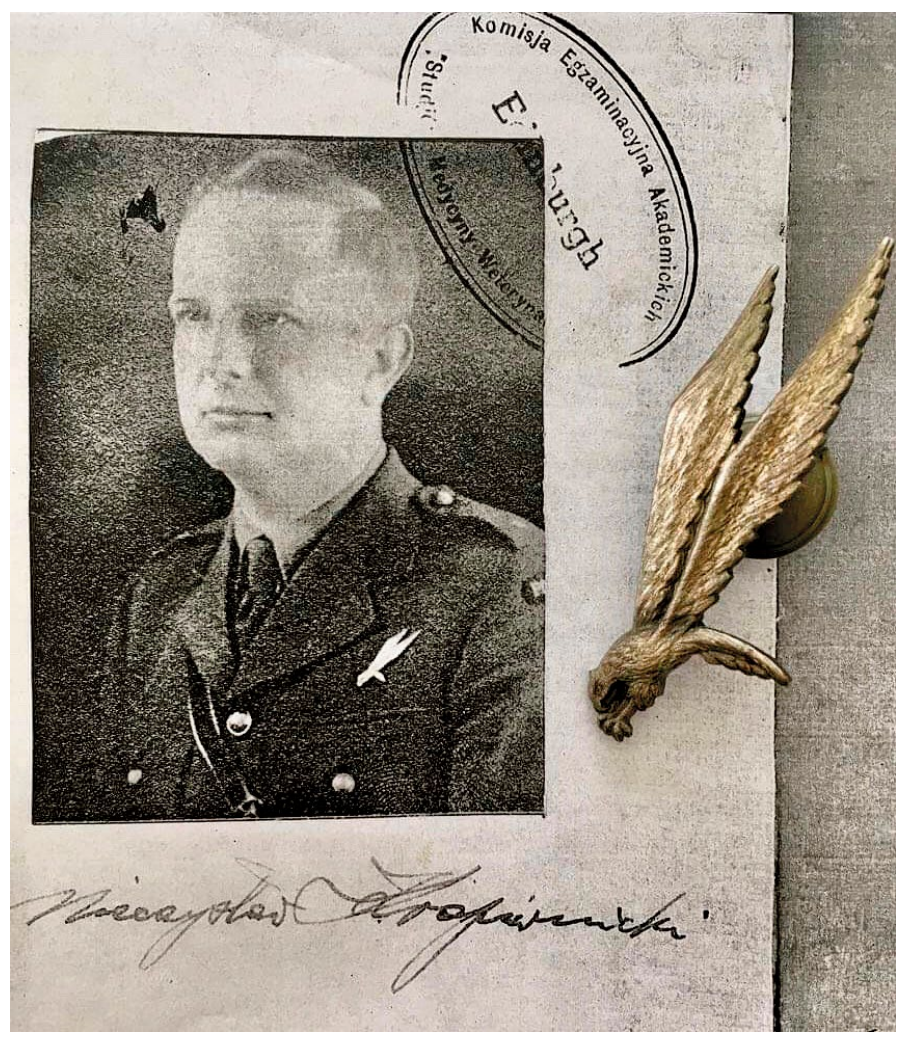

Fig. 3. Dr Mieczysław Jan de Sas Kropiwnicki during his veterinary studies in Edinburgh with his Cichociemni paratrooper badge

Niżniów and had probably now been lost or destroyed. His professors had either died or were detained in Soviet concentration camps. Here in Britain he had a chance to qualify again. The London Government had money to offer as stipends to Polish students, thanks to the Polish gold which was smuggled from Poland in 1939 and deposited into the Bank of England. There were English universities that created faculties for Polish students who wanted to finalize their studies. One of them was the Royal Dick Veterinary College in Edinburgh. Mieczysław had to apply for temporary leave from the Army and a grant or stipend from the Interim Treasury Committee.

All the time, Mieczysław wanted to go to Poland. He applied to the High Command for permission to be dropped there at the earliest date. However, permission was not granted and instead he was transferred to the School Brigade in Kinghorn, Scotland. He suspected that Father Bełch had something to do with this matter.

He applied to study at the Medical Veterinary College in Edinburgh and he was granted leave of temporary absence from the Army. As a result, he began his studies on the $15^{\text {th }}$ of October 1942 (Fig. 3). The principal lecturers were Professor Dr. Stanisław Runge, Professor Tadeusz Olbrycht, Professor Stanisław Mglej and Professor Józef Kulczycki. They were all very strict and demanding, but also reasonable. Mieczysław had no problems with most of them except for Professor of Surgery Dr. Kulczycki. He always tried to find something wrong with Mieczysław's practical 
work. It was ironic because surgery always remained Mieczysław's favourite subject and he excelled at it.

Every year Mieczysław had to apply for an extension of leave from the Army. It was always granted on the grounds that there would be a great demand for veterinary surgeons in the new Poland for which they were now fighting.

Mieczysław finished his final examinations and practical tests in 1944. He was awarded a degree in Veterinary Surgery. This also entitled him to obtain a Doctor of Veterinary Medicine degree. The degree he received enabled him to practice veterinary medicine and surgery according to the laws of the Polish Republic.

The uprising which broke out in Warsaw in August 1944 was unexpected and such exciting news. Mieczysław was eager to join the Parachute Brigade and take part in the battle of Warsaw. He was hoping that this time his luck would hold and that he would be accepted for the jump. Unfortunately there was a new disappointment waiting him. The British Government refused to allow the Parachute Brigade to participate in the action based on political, technical and other reasons. There was an outcry and a rebellion amongst the troopers. General Sosabowski had to intervene although he was for their participation and action in Warsaw. Warsaw had fallen after nine weeks of heroic attempts to free the city. Mieczysław returned to Edinburgh and applied to study surgery with Professor Formston at the Royal Veterinary College in Streatley. His application was granted till the $18^{\text {th }}$ May 1945.

On the $8^{\text {th }}$ of May 1945, World War II came to an end with the unconditional surrender of the Axis powers. However, the Poles had no desire to celebrate. The Yalta and Potsdam Conferences in which Churchill, Roosevelt and Stalin participated, had determined the post-war borders in Europe. Poland was given to the Soviet sphere of domination. The Polish leaders were never even consulted and the London Government lost its credibility. Mieczysław cried for his Niżniów and Lwów which were now lost forever.

He was still in the Army and after the war he was allocated to various infantry centres in Scotland. For a while he was also stationed at the Registration Office of the Infantry Regiment in London. Again, Father Bełch encouraged Mieczysław to be patient and continue with his studies.

Mieczysław was so proud of having a son and desperately wanted to return to Poland. However, the danger of such action was great. There were many stories of arrests, prisons and torture of people who were returning home to Poland. Those who returned were considered terrorists who wanted to destroy the present communist regime. Mieczysław knew of a few of his colleagues who had disappeared without a trace on their return. He started to contemplate emigration.
Mieczysław realised that his recent degree in veterinary medicine would not be accepted outside Poland, and even in Poland he would probably have trouble being accepted as a qualified veterinary doctor. He needed a degree that would be acceptable all over the whole world.

Mieczysław was offered a teaching post for veterinary subjects at the Polish agricultural school in Glasgow and the Army accepted his transfer. While teaching he began to make inquiries at the Glasgow Royal College of Veterinary Medicine about the nostrification of his degree. They accepted him as an external student for the final year and he passed all the required examinations in 1947. Thereafter he was fully qualified to practise the Art and Science of Veterinary Surgery and Medicine and he was declared a member of the Royal College of Veterinary Surgeons by order of the Council. At the graduation ceremony he was handed his degree, which had the stamp of the Royal College of Veterinary Surgeons and was dated the July 10, 1947.

He was now qualified to practice in all British dominions and after some consideration, he made some inquiries at the South African Embassy in London. There he met a British veterinary surgeon and he recommended South Africa, saying that there was a shortage of qualified veterinarians in that country.

He moved to South Africa in 1948 and started a practice in the Transvaal. Subsequently, he practised at Tweespruit and Ladybrand in the Orange Free State and in Barkly East in the Northern Eastern Cape, where he was active from 1952 until 1966. It was during this time in Barkly East that Mieczysław performed a caesarean section on a brood mare (1958).

In South Africa, Mieczyslaw remarried a Polish woman named Aleksandra (Oleńka) Anna Hall. They had two children named Alexander (Oleś) and Anna Barbara (Basia).

From 1966 until 1969 he was a Veterinary Officer in Botswana. However, a severe stroke forced him to retire. He moved to East London (South Africa), where he passed away on the $15^{\text {th }}$ August 1971.

Mieczysław's Cichochiemni paratrooper wings have become one of my favourite personal historical items. To me they represent patriotism, bravery, excellence and resilience. After being in exile since 1940, I am happy to say that Mieczystaw's Cichociemni paratrooper wings have finally returned to Poland (on the $22^{\text {nd }}$ of August 2020)! In addition, I am to start my collaboration with the Medical University of Gdansk in the field of Medical Chemistry. We have finally returned back to Poland...

While examining the unfolding life and attitude of Mieczysław Sas-Kropiwnicki, one realises that he was a remarkable character. Not only as a Pole and a patriot, but he was also a member of nobility who was 


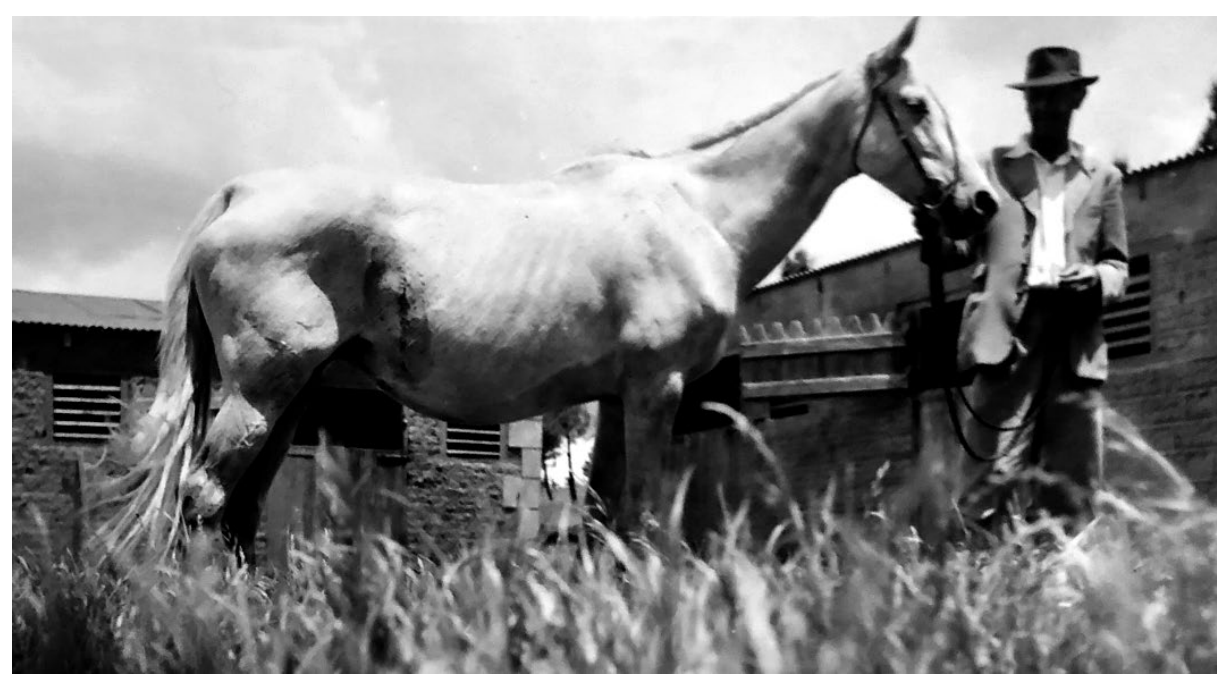

Fig. 4. Broodmare "Smart Girl" after caesarean section (with visible scar after surgery in the right flank)

surrounded by the mist of fame and glory associated with the Cichociemni group. In addition, he was also a distinguished representative of the veterinary profession, taking on exceptional challenges in this field.

After being awarded with a title of a veterinarian, Mieczysław Sas-Kropiwnicki started his work as a practicing veterinarian in RSA. We can discover some of his professional accomplishments not only by reading the book that his wife wrote about their shared experiences in Africa (1), but also by following his publications that consistently appeared in world-class professional literature (3-7), some of which was Polish $(3,5)$. In fact, even though he was living-at-the-farend-of-the-world, Dr Sas-Kropiwnicki's works were being also published in Medycyna Weterynaryjna. This undeniably indicates that he had never forgotten his roots.

Amongst the special achievements of Dr SasKropiwnicki is the story of a successful caesarean section carried out on a mare named 'Smart Girl' in RSA in 1957 (4) (Fig. 4). This achievement places dr Kropiwnicki among the top pioneers of this delivery aid technique in the world, since until then not many such procedures had ever been carried out successfully. Dr Kopiwnicki notes and reflections at the end of "The Veterinary Record" article are fascinating and prophetic, especially in light of the popular convictions held at that time. While simultaneously reflecting the exotic conditions in which the author was operating, it is worthwhile looking at his citation record from the chapter of the original article (4):

The operation described above was performed in the open veld under the blazing South African sun, while the wind occasionally caused dust, hairs, and dry grass to settle on the wound. The Europeans and natives who assisted were quite untrained and inexperienced so that it was difficult to get them to observe the rules of asepsis. The mare was 14-years-old and had spent the night in labour. The author was unprepared for the operation, and consequently had no choice of anaesthetics - his surgery being 20 miles distant. There was need for haste in performing the operation as it was impossible to provide any kind of shade, and the blazing sun caused the blood to dry rapidly.

It has generally been accepted that laparotomy on a horse is dangerous because of the risk of infection and peritonitis, and because of the difficulty in handling the considerable amount of bulging intestines. Thus, taking the unfavourable and difficult conditions described above into account it would appear that there is no appreciably greater risk attached to laparotomy in a horse than there is in other animals such as sheep, cows, etc.

The author frequently performs caesarean operations on sheep and cows, and he considers that all in all there is not much more work attached to carrying out this operation on horses.

Dr Kropiwnicki also described a few of his other operations, which prove his advanced surgical skills. For example depiction of a unilateral ovariectomy on a mare published in 1964 in an American journal (7), and a report on a reposition of a caecum volvulus operation on a cow proceeded by a rumenotomy (6), both demonstrate his knowledge and surgical skills. In addition to these articles describing chosen surgical procedures, Dr Kropiwnicki published two articles about infectious diseases (both published in Polish in Medycyna Weterynaryjna $(3,5)$.

While co-creating the publication on the history of the caesarean section on a mare and citing the work of Dr Sas-Kropiwnicki, I could not have expected that it would lead me to discover the story of such an exceptional man and his tangled fortune; and that it would allow me to get in touch with his grandson and initiate a collaboration that resulted in the story above.

\section{Literature}

1.Bereznowski A., Rakowska A., Górski K., Dziekan P., Szara T., Witkowski M. Cesarskie cięcie u klaczy - rys historyczny zabiegu, jego ewolucja oraz perspektywy na tle innych technik pomocy porodowej. Med. Weter. 2020, 76, 82-86.

2. Kropiwnicka A. S.: Olenka in London. Self-published, 2018.

3. Kropiwnicki M. J. S.: Anaplazmoza bydła. Med. Weter. 1962, 28, 75-78.

4. Kropiwnicki M. J. S.: Cesarean section on a mare. Veterinary Record. 1958, $70,557$.

5. Kropiwnicki M. J. S.: Pomór koni. Med. Weter. 1960, 26, 707-710.

6. Kropiwnicki M. J. S.: Surgical treatment of the volvulus and tympany of the cecum of the cow. The quarterly bulletin of the eastern cape branch of the S.A.V.M.A., 2, 3-4, 1964.

7. Kropiwnicki M. J. S.: Unilateral ovariectomy in a mare. J. Am. Vet. Med. A. 1964, 144, 1389-1390.

Corresponding Author: Dr hab. Maciej Witkowski, Uniwersyteckie Centrum Medycyny Weterynaryjnej UJ-UR, al. Adama Mickiewicza 24/28, 30-059 Kraków 